ORIGINAL ARTICLE

\title{
Yeasts and moulds contaminants of food ice cubes and their survival in different drinks
}

\author{
N. Francesca ${ }^{1}$, R. Gaglio ${ }^{1}$, C. Stucchi ${ }^{2}$, S. De Martino ${ }^{2}$, G. Moschetti ${ }^{1}$ and L. Settanni ${ }^{1}$ \\ 1 Dipartimento Scienze Agrarie, Alimentari e Forestali, Università di Palermo, Palermo, Italy \\ 2 INGA, Istituto Nazionale Ghiaccio Alimentare, Roma, Italy
}

Keywords

beverages, drinks, ice cubes, moulds, survival test, yeasts.

\author{
Correspondence \\ Raimondo Gaglio, Dipartimento Scienze \\ Agrarie, Alimentari e Forestali, Università di \\ Palermo, Viale delle Scienze 4, 90128 \\ Palermo, Italy. \\ E-mail: raimondo.gaglio@unipa.it
}

2017/1248: received 28 June 2017, revised 13 October 2017 and accepted 20 October 2017

doi:10.1111/jam.13624

\begin{abstract}
Aims: To evaluate the levels of unicellular and filamentous fungi in ice cubes produced at different levels and to determine their survival in alcoholic beverages and soft drinks.

Methods and Results: Sixty samples of ice cubes collected from home level (HL) productions, bars and pubs (BP) and industrial manufacturing plants (MP) were investigated for the presence and cell density of yeasts and moulds. Moulds were detected in almost all samples, while yeasts developed from the majority of HL and MP samples. Representative colonies of microfungi were subjected to phenotypic and genotypic characterization. The identification was carried out by restriction fragment length polymorphism (RFLP) analysis of the region spanning the internal transcribed spacers (ITS1 and ITS2) and the 5.8S rRNA gene. The process of yeast identification was concluded by sequencing the D1/D2 region of the $26 \mathrm{~S}$ rRNA gene. The fungal biodiversity associated with food ice was represented by nine yeast and nine mould species. Strains belonging to Candida parapsilosis and Cryptococcus curvatus, both opportunistic human pathogens, and Penicillium glabrum, an ubiquitous mould in the ice samples analysed, were selected to evaluate the effectiveness of the ice cubes to transfer pathogenic microfungi to consumers, after addition to alcoholic beverages and soft drinks. All strains retained their viability.

Conclusions: The survival test indicated that the most common mode of consumption of ice cubes, through its direct addition to drinks and beverages, did not reduce the viability of microfungi.

Significance and Impact of the Study: This study evidenced the presence of microfungi in food ice and ascertained their survival in soft drinks and alcoholic beverages.
\end{abstract}

\section{Introduction}

Fungi are the colonizers of several different environments. This phenomenon is mainly due to their high general competitive saprophytic ability (Griffin 1960). Moisture plays a defining role in the determination of the fungal community distribution and structure (Jacobson 1997). For this reason, yeasts and moulds dominate the microflora on raw fruits and vegetables (Beuchat 2002). Furthermore, some eukaryotic micro-organisms are able to grow at refrigeration temperatures (Li et al. 2001; Viljoen 2001). In general, several microfungi such a penicillia and most soil fungi can be considered ubiquitous (Fischer and Dott 2003) and can be easily dispersed in air (Adams et al. 2013). Fungi are increasingly gaining importance in view of health hazards and are relevant for indoor hygiene (Fischer and Dott 2003). The primary health impacts from fungi are faced by immunocompromised people, and are caused by inhalation and/or wound infection. Inhalation can lead to worsening of asthma symptoms, pneumonitis or fungal infection. Additionally, exposure of mucosal membranes to fungi may lead to airway infection (Novak Babič et al. 2017).

Several studies focused on the emerging pathogenic microfungi, their routes of contamination and the environmental factors that favour the process of colonization 
(Dynowska and Kisicka 2005; Gogu-Bogdan et al. 2014). The occurrence of fungi in drinking water has received increased attention in the last decades, and fungi are now generally accepted as drinking water contaminants (Hageskal et al. 2009). Furthermore, the presence of yeasts and yeast-like fungi in tap water and groundwater, and their transmission to household appliances has been recently evaluated (Novak Babič et al. 2016). Although ingestion is not generally considered a risk factor for fungal infections, fungi in drinks (and ice) may indicate potential risks from other water uses.

Food grade ice is the product obtained through the freezing of potable water. In general, as for water, the hygienic status of ice is determined by the presence of intestinal bacteria (Lateef et al. 2006; Ukwo et al. 2011) that are faecal indicators. Due to the increased worldwide request of ice cubes for human consumption, commonly added to cool drinks, the number of food ice industries increased proportionally, although a consistent production of ice cubes occurs by low volume ice cube maker machines (self-production), especially in bars, pubs and restaurants (Gaglio et al. 2017). The self-production of ice cubes is strictly intended for direct consumption, while industrial productions are packed in bags and commercialized. The Packaged Ice Quality Control Standards manual published by the International Packaged Ice Association provides the quality and processing standards for packaged ice produced by its members, even though the quality and safety of packaged ice products is not consistent (Lee et al. 2017).

In general, the microbiological investigations of ice focus on plate counts and the application of biochemical tests for the identification of the major pathogenic bacteria, mainly Escherichia coli, Salmonella spp., Yersinia spp., Pseudomonas aeruginosa, Clostridium perfringens, Shigella spp., Vibrio cholerae and Aeromonas spp. (Nichols et al. 2000; Falcao et al. 2002; Gerokomou et al. 2011; Noor Izani et al. 2012; Awuor et al. 2016; Hampikyan et al. 2017). However, the presence of micro-organisms in ice cubes is not only due to the contamination of the water used (Lateef et al. 2006; Northcutt and Smith 2010), to the scarce hygienic conditions during production and the improper handling (Noor Izani et al. 2012), to the packaging containers or bags (Chavasit et al. 2011), but it also depends on the contamination by aerosol. Thus, the presence of microfungi deserves attention. In fact, these agents can be pathogenic and possess all characteristics to be spread through ice consumption. To support this thesis, psychrophilic yeasts have been reported in extremely cold environment such as Arctic, Antarctic and alpine snow (Anesio et al. 2017). Studies of fungi in drinking water have demonstrated that they are relatively common in water distribution systems. Species of pathogenic, allergenic and toxigenic concern are isolated from water, sometimes in high concentrations (Hageskal et al. 2009). The species more frequently found include some opportunistic human pathogens such as Candida and Fusarium species (Novak Babič et al. 2015, 2016).

Based on the above considerations, the aim of the present work was to: (i) evaluate the presence and levels of unicellular and filamentous fungi of food ice produced a three different levels, including small volume (homemade), medium volume (restaurant level) and high volume (industrial level) facilities; (ii) perform phenotypic and genotypic characterization of the isolates; (iii) monitor the survival of representative strains in different alcoholic beverages and soft drinks.

\section{Materials and methods}

\section{Sample collection}

The samples of ice cubes were collected from domestic freezers, produced at home level (HL) and representing the "from freezer to glass" route without any additional manipulation (Gaglio et al. 2017), from ice holding/storage equipment of bars and pubs (BP), for the selfproductions performed with low volume ice machines representing the production stored without bags, and from sales packages of ice produced by industrial manufacturing plants (MP) and sold in plastic bags. Five producers per each production level (HL1-HL5, BP1-BP5, MP1-MP5) were selected within the Palermo province (Sicily, Italy), in order to border the source of water supply. Domestic and bar/pub samples were collected aseptically and transferred into sterile stomacher bags, while the industrial samples were left in the manufacturers' plastic bags during transport. All productions were performed with tap water supplied by the municipal source. Five houses/bars/industrial plants were investigated for each production level and four samples were collected in duplicate (the same day) at a 2-month interval from each plant. Thus, a total of 60 samples were collected to perform this study. The samples were transported into thermal insulated boxes.

\section{Microbiological analyses of ice samples}

Depending on the weight of single ice cubes (ranging between 10 and $20 \mathrm{~g}$ approximately for the different shapes), about 25-50 cubes corresponding to $500 \mathrm{~g}$ were left thawing in a 11 sterile Dhuram bottle at ambient temperature. Two $100 \mathrm{ml}$ aliquots from each sample collected were separately analysed by membrane filtration in order to investigate unicellular and filamentous fungi. Both eukaryotic microbial groups were inoculated on 
malt agar (Oxoid, Milan, Italy) supplemented with $0.1 \mathrm{~g}^{-1}$ chloramphenicol (Sigma-Aldrich, Milan, Italy) to avoid bacterial growth. For the determination of yeasts the plates were incubated at $28^{\circ} \mathrm{C}$ for $48 \mathrm{~h}$, while for moulds at $25^{\circ} \mathrm{C}$ for $7 \mathrm{~d}$. When the number of colonies from a given sample exceeded the number of squares $(n=186)$ present on the membrane grid, or several colonies showed a clear confluent growth, aliquots of $1 \mathrm{ml}$ from this sample were directly inoculated onto malt agar (Oxoid). Two 1-ml aliquots were collected after vigorous manual agitation of thawed ice.

\section{Isolation and grouping of yeasts and moulds}

After growth, colonies of yeasts were picked up from the plates. For each morphology (colour, margin, surface and elevation), five identical colonies (or fewer if five were not available or showed confluent growth) were collected. Yeast isolates were subjected to purification after several consecutive subcultures onto malt agar incubated at $28^{\circ} \mathrm{C}$ for $48 \mathrm{~h}$. The purity of the cultures was verified by an optical microscope and the yeasts were grouped on the basis of their cell morphology.

Several mould colonies were picked up from agar plates and purified to homogeneity after several subculturing steps onto malt agar until each colony reached the diameter of about $2 \mathrm{~mm}$. The isolates were differentiated by macroscopic characterization including colour, texture, diffusible pigments, exudates, growth zones, aerial and submerged hyphae, growth rate and topography. The taxonomic investigation was also performed through microscopic characterization of the isolates including the analysis of stipes, vesicles, phialides, metulae and conidia (Barnett and Hunter 1998; Domsh et al. 2007).

\section{Genetic identification}

Fresh pure cultures of yeasts and moulds were subjected to DNA extraction by lysis applying the Instagene Matrix kit (Bio-Rad, Hercules, CA, USA) following the manufacturer's instruction and the cell extracts were used as templates for PCRs.

All yeast isolates were preliminary grouped by restriction fragment length polymorphism (RFLP) analysis of the region spanning the internal transcribed spacers (ITS1 and ITS2) and the 5.8S rRNA gene as reported by Esteve-Zarzoso et al. (1999). Each reaction mixture contained $0.5 \mu \mathrm{mol} \mathrm{l}^{-1}$ primer ITS 1 ( $5^{\prime}$ TCCGTAGGTGAA CCTGCGG $3^{\prime}$ ), $0.5 \mu \mathrm{mol} \mathrm{l}^{-1}$ primer ITS4 (5' TCCTCC GCTTATTGATATGC $3^{\prime}$ ), $10 \mu \mathrm{mol} \mathrm{l}^{-1}$ deoxynucleotides mix (Life Technologies Italia, Monza, Italy), $1.5 \mathrm{mmol}$ $1^{-1} \mathrm{MgCl}_{2}$, and $1 \times$ buffer (Fermentas, MMedical, Milan, Italy). Prior amplification, performed by a T1 Thermocycler
(Biometra, Göttingen, Germany), the suspension was heated at $95^{\circ} \mathrm{C}$ for $15 \mathrm{~min}$ and then $1 \mathrm{U}$ of Taq DNA polymerase (Fermentas), 2.5 ng of DNA, and Milli- ${ }^{\circledR}$ water (Millipore, Billerica, MA, USA) were added to each tube reaching the final reaction volume of $20 \mu$ l. The PCR program applied comprised 35 cycles of denaturation for $1 \mathrm{~min}$ at $94^{\circ} \mathrm{C}$, annealing for $2 \mathrm{~min}$ at $55.5^{\circ} \mathrm{C}$, and extension for $2 \mathrm{~min}$ at $72^{\circ} \mathrm{C}$; the cycles were preceded by denaturation at $95^{\circ} \mathrm{C}$ for $5 \mathrm{~min}$ and followed by extension at $72^{\circ} \mathrm{C}$ for $10 \mathrm{~min}$. The amplicons $(10 \mu \mathrm{l})$ were digested overnight at $37^{\circ} \mathrm{C}$ without further purification with the restriction endonucleases CfoI, HaeIII and Hinfl (Fermentas) The PCR products and their restriction fragments were separated on $1.4 \%$ and $3 \%$ agarose gels, respectively, with $1 \times$ TAE buffer, stained with $\mathrm{SYBR}^{\circledR}$ Safe DNA gel stain (Molecular Probes, Eugene, OR, USA), and subsequently visualized by UV transillumination. The GeneRuler 50 bp Plus DNA Ladder (MMedical S.r.l, Milan, Italy) was used as a molecular weight marker.

The isolates representative of each RFLP group were identified at species level by sequencing the D1/D2 region of the 26S rRNA gene to confirm the preliminary identification obtained by RFLP analysis. D1/D2 region was amplified and the PCR products visualized as described by Francesca et al. (2014). PCR reactions were performed using the primer pair NL1/NL4 (O'Donnell 1993) in a $30 \mu \mathrm{l}$ reaction volume. PCR mixture contained 0.25 mmol $\mathrm{l}^{-1}$ of dNTP mix (Life Technologies Italia), 1.5 U of Taq DNA polymerase (Fermentas), $3 \mu \mathrm{l}$ of PCR buffer containing $20 \mathrm{mmol} \mathrm{l}^{-1} \mathrm{MgCl}_{2}$ (Fermentas), $0.2 \mu \mathrm{mol}$ $1^{-1}$ of both primers, $25 \mathrm{ng}$ of DNA, and was brought to the final volume with Milli- ${ }^{\circledR}$ water (Millipore). PCR program comprised an initial template denaturation step for $5 \mathrm{~min}$ at $95^{\circ} \mathrm{C}$ followed by 30 cycles of denaturation for $1 \mathrm{~min}$ at $95^{\circ} \mathrm{C}$, annealing for $45 \mathrm{~s}$ at $52^{\circ} \mathrm{C}$ and extension for $1 \mathrm{~min}$ at $72^{\circ} \mathrm{C}$. The final elongation step was for $7 \mathrm{~min}$ at $72^{\circ} \mathrm{C}$.

The identification of moulds was concluded genetically. Genomic DNA was extracted from single spore cultures following a standard cetyl-trimethyl-ammonium-bromide-based protocol (O’Donnell et al. 1998). Sequencing of the 5.8S-ITS rRNA gene were performed as described by Alfonzo et al. (2013). PCR reactions were performed using the primer pair ITS1f/ITS4 in a $40 \mu \mathrm{l}$ reaction volume. PCR mixture contained $0.40 \mathrm{mmol} \mathrm{l}^{-1}$ of dNTP mix (Life Technologies Italia), $2.5 \mathrm{U}$ of Taq DNA polymerase (Fermentas), $4 \mu \mathrm{l}$ of PCR buffer containing $20 \mathrm{mmol} \mathrm{l}^{-1} \mathrm{MgCl}_{2}$ (Fermentas), $0 \cdot 25 \mu \mathrm{mol} \mathrm{l}^{-1}$ of both primers, $25 \mathrm{ng}$ of DNA, and was brought to the final volume with Milli- ${ }^{\circledR}$ water (Millipore). PCR program comprised an initial template denaturation step for $2 \mathrm{~min}$ at $95^{\circ} \mathrm{C}$ followed by 34 cycles of denaturation for 
$30 \mathrm{~s}$ at $95^{\circ} \mathrm{C}$, annealing for $20 \mathrm{~s}$ at $55^{\circ} \mathrm{C}$ and extension for $1 \mathrm{~min}$ at $72^{\circ} \mathrm{C}$. The final elongation step was for $5 \mathrm{~min}$ at $72^{\circ} \mathrm{C}$.

DNA fragments from yeast and mould DNAs were visualized and the amplicons were purified by the QIAquick purification kit (Qiagen S. p.a., Milan, Italy) and sequenced using the same primers employed for PCR amplification. DNA sequencing reactions were performed by AGRIVET (Palermo, Italy). The identity of yeast and mould sequences was determined by comparison with the sequences available in the GenBank/EMBL/DDBJ (http:// www.ncbi.nlm.nih.gov). All sequences were deposited in GenBank under their accession numbers.

\section{Artificial contamination of ice cubes and survival of yeasts and moulds in different systems}

The strains of yeasts and moulds found at the highest levels in the ice cubes and belonging to species known as human pathogens were inoculated at the same levels detected in commercial ice cubes and tested for their survival in alcoholic beverages, such as vodka (Keglevich, Plzen, Czech Republic), whisky (Jack Daniel's, Lynchburg, Tennessee) and Martini (Martini and Rossi, SpA, Pessione, Italy) containing 38,40 and $14 \cdot 4 \%$ vol of alcohol, respectively, and soft drinks, such as peach tea (Conad, Fruttagel SCpA, Alfonsine, Italy), tonic water (Kinley, Sesto S. Giovanni, Italy) and coke (Coca Cola Italia Srl, Sesto S. Giovanni, Italy). These systems were previously chosen by Gaglio et al. (2017) as being characterized by different $\mathrm{pH}$, alcohol volume, sugar content, presence or absence of $\mathrm{CO}_{2}$ and antimicrobial compounds. Ringer's solution (Oxoid) was used to perform the control trial, in order to exclude any inhibitory effect due to the chemical components of the drink systems.

Yeast and mould strains were first cultivated under their optimal growth conditions. Yeast cells were washed twice in Ringer's solution (Sigma-Aldrich, Milan, Italy), centrifuged at $5000 \times \mathrm{g}$ for $5 \mathrm{~min}$ at $4^{\circ} \mathrm{C}$ and then suspended singly in sterile (treatment at $121^{\circ} \mathrm{C}$ for $20 \mathrm{~min}$ ) still mineral water (Terme di Geraci Siculo S.p.a., Geraci Siculo, Italy). The levels of yeast inocula occurred at the highest cell densities found in the samples analysed which was checked spectrophotometrically (optical density at $600 \mathrm{~nm}$ ) by a 6400 Spectrophotometer (Jenway Ltd., Felsted, Dunmow, UK) and confirmed by plate count on malt agar. Filamentous fungus propagules were collected after mycelium growth by means of a sterile surgical blade and re-suspended in Ringer's solution. Spore concentration was determined by Burker's chamber (Carl Zeiss, Oberkochen, Germany). In order to ensure the presence of the sole micro-organism to be tested, contaminated ice cubes were produced using autoclaved stainless steel ice cube trays at $-32^{\circ} \mathrm{C}$. The test was performed as follows: three artificially inoculated ice cubes (corresponding to $60 \mathrm{ml}$ ) were added to $100 \mathrm{ml}$ of each drink in $200 \mathrm{ml}$ volume sterile cups (Anicrin, Scorzé, Italy) and left $1 \mathrm{~h}$ at room temperature before membrane filtration analysis. Three independent experimentations were carried out.

\section{Statistical analyses}

Yeast and mould loads were subjected to one-way analysis of variance (ANOVA). Pair comparison of treatment means was achieved by Tukey's procedure at $P<0.05$. Differences between the production levels (HL, BP and MP) were evaluated with the Generalized Linear Model (GLM) procedure. The statistical analysis was conducted with SAS 9.2 software (Statistical Analysis System Institute Inc., Cary, NC, USA).

\section{Results}

\section{Levels of fungi in the ice cubes}

The levels of yeasts and moulds in the ice cube samples analysed were expressed as colony forming units (CFU) per $100 \mathrm{ml}$ of thawed ice (t.i.). and are reported in Table 1 . Although filtration is not an invasive treatment responsible for the damage of mould colonies, it cannot be excluded that hyphae and conidia from a single colony generated multiple colonies of the same type. Plate counts showed statistical significant differences $(P \leq 0.001)$ among the samples collected within the three production levels for both groups investigated. Except sample MP1, moulds were always registered with levels ranging between 0.8 and 195.3 CFU per $100 \mathrm{ml}$ t.i., while yeasts developed from the majority of HL and MP samples and only two BP samples. Interestingly, the levels of moulds were below $10 \mathrm{CFU}$ per $100 \mathrm{ml}$ t.i. for 10 ice samples, including all those produced at industrial level. Regarding yeasts, the highest numbers were registered for the domestic samples, in particular, a cell density of 383.8 CFU per $100 \mathrm{ml}$ t.i. was displayed by the samples HL5. The statistical analysis resulting from the interaction of load data for the three ice cube production levels $(\mathrm{HL} \times \mathrm{BP} \times \mathrm{MP})$ indicated that yeast and mould levels were significantly different $(P \leq 0.001$ and $P \leq 0.05$, respectively).

Biodiversity of eukaryotic micro-organisms associated to the ice cubes

After enumeration, colonies of yeasts and moulds were isolated from malt agar. All different morphologies present in plates were collected and purified before 
Table 1 Levels of yeasts and moulds of ice cubes produced at different levels†

\begin{tabular}{|c|c|c|c|}
\hline \multirow{2}{*}{$\begin{array}{l}\text { Ice } \\
\text { "samples }\end{array}$} & \multirow[b]{2}{*}{ Cities: } & \multicolumn{2}{|c|}{ Microbial groups§ } \\
\hline & & Yeasts & Moulds \\
\hline HL1 & Palermo & $0^{A}$ & $17.5 \pm 2.4^{\mathrm{D}}$ \\
\hline $\mathrm{HL} 2$ & Villabate & $0^{A}$ & $35 \cdot 5 \pm 4 \cdot 1^{\mathrm{E}}$ \\
\hline HL3 & $\begin{array}{l}\text { Termini } \\
\text { imerese }\end{array}$ & $253.5 \pm 24 \cdot 1^{c}$ & $1.0 \pm 0^{\mathrm{A}}$ \\
\hline HL4 & Castelbuono & $39 \cdot 5 \pm 2 \cdot 1^{\mathrm{B}}$ & $12.8 \pm 1.7^{C}$ \\
\hline HL5 & $\begin{array}{l}\text { San Giuseppe } \\
\text { Jato }\end{array}$ & $383 \cdot 8 \pm 20 \cdot 5^{\mathrm{D}}$ & $2 \cdot 3 \pm 1 \cdot 5^{B}$ \\
\hline $\begin{array}{l}\text { Statistical } \\
\text { significance }\end{array}$ & & $* * *$ & $\star * *$ \\
\hline BP1 & Palermo & $43.5 \pm 14 \cdot 1^{B}$ & $7 \cdot 3 \pm 1 \cdot 5^{C}$ \\
\hline BP2 & Palermo & $0^{A}$ & $2.3 \pm 0.5^{B}$ \\
\hline BP3 & Palermo & $0^{A}$ & $2 \cdot 0 \pm 1 \cdot 2^{B}$ \\
\hline BP4 & Castelbuono & $116 \cdot 5 \pm 6 \cdot 0^{c}$ & $0.8 \pm 0.5^{\mathrm{A}}$ \\
\hline BP5 & Palermo & $0^{A}$ & $195 \cdot 3 \pm 21.4^{\mathrm{D}}$ \\
\hline $\begin{array}{l}\text { Statistical } \\
\text { significance }\end{array}$ & & $* * *$ & $\star * *$ \\
\hline MP1 & Not available & $0.8 \pm 0.5^{B}$ & $0^{A}$ \\
\hline MP2 & Not available & $16 \cdot 3 \pm 3 \cdot 0^{\mathrm{D}}$ & $1.0 \pm 0.8^{B}$ \\
\hline MP3 & Not available & $3.5 \pm 1.7^{C}$ & $1 \cdot 3 \pm 1.0^{\mathrm{B}}$ \\
\hline MP4 & Not available & $1 \cdot 3 \pm 1 \cdot 0^{\mathrm{B}}$ & $6.5 \pm 1.9^{c}$ \\
\hline MP5 & Not available & $0^{A}$ & $0.8 \pm 0.5^{\mathrm{B}}$ \\
\hline $\begin{array}{l}\text { Statistical } \\
\text { significance }\end{array}$ & & $* * *$ & $* * *$ \\
\hline $\begin{array}{l}\text { Interaction among } \\
\text { the production } \\
\text { levels } \\
(\mathrm{HL} \times \mathrm{BP} \times \mathrm{MP})\end{array}$ & & $* * *$ & * \\
\hline
\end{tabular}

$\mathrm{HL}$, home level; BP, bars and pubs; MP, manufacturing plants.

Results indicate mean values \pm SD of four microbiological counts (carried out in duplicate for two independent sample collections).

Data within a column followed by the same letter are not significantly different according to Tukey's test.

$\dagger$ CFU per $100 \mathrm{ml}$ of thawed ice.

$\$$ All cities are located within Palermo province (Sicily, Italy).

$\S$ Yeasts on malt agar incubated for $48 \mathrm{~h}$; moulds on malt agar incubated for 7 days.

${ }^{*} P \leq 0.05 ; * * * \leq 0.001$.

microscopic inspection. After the preliminary characterization of the eukaryotic micro-organisms, based exclusively on colony and cell morphology, 153 yeasts and 81 filamentous fungi were selected for the genetic identification.

The combination of band lengths from 5.8S-ITS and the RFLP profiles allowed the identification of nine yeast species (Ac. No. KX609387 - KX609392, KX609394 KX609396) from the nine ice samples positive for the growth of unicellular fungi (Table 2). A single species was found associated with each HL ice cube production; in particular, Metschnikowia sp., Meyerozyma guilliermondii and Cystobasidium slooffiae were identified from the samples HL3, HL4 and HL5 respectively. A higher biodiversity of yeasts was revealed for the ice cubes collected from bars and pubs, since the only two productions positive for the development of colonies on malt agar after $48 \mathrm{~h}$ of incubation contained two species each: Candida intermedia and Cryptococcus curvatus from sample BP1, while Pichia guilliermondii and Yarrowia lipolytica from BP4. The most limited yeast diversity was observed for the industrial ice cubes with two species in four samples, Candida parapsilosis in MP3 and Rhodotorula mucilaginosa in MP1, MP2 and MP4.

The direct comparison of the 5-8S-ITS sequences of filamentous fungi with those available in NCBI indicated that the ice cubes hosted the following species: Fusarium sp., Fusarium solani, Hansfordia sp., Paecilomyces sp., Paecilomyces lilacinus, Penicillium glabrum, Phoma leveillei, Purpureocillium sp. and Thanatephorus cucumeris (Ac. No. KX609397 - KX609405). Regarding their sample of isolation, the home-made ice cubes were contaminated by Hansfordia sp. (one sample, HL3) and P. glabrum (all samples), those collected from bars and pubs by Pc. lilacinus, Ph. leveillei, Purpureocillium sp. and T. cucumeris, almost equally distributed in the different samples, while the four industrial samples hosted Paecilomyces sp., and Fusarium sp.

\section{Yeast and mould survival in beverages and drinks}

The strains used to test the persistence of unicellular and filamentous fungi of ice origin in drink systems characterized by different conditions belonged to the species C. parapsilosis (strain ICE214) and Cr. curvatus (strain ICE84) among yeasts, since they are reported as human pathogens, while P. glabrum (strain ICE139) was chosen among moulds due to its ubiquity among ice samples. Mineral water after autoclave sterilization, as well as all beverages and drinks before ice addition, did not contain any viable micro-organisms as detected by membrane filtration analysis. The three strains were inoculated at the highest levels found for yeasts and moulds during the microbiological ice cube characterization. For this reason, the artificially contaminated ice cubes were produced with yeasts and moulds at levels in the range 200$400 \mathrm{CFU}$ per $100 \mathrm{ml}$ t.i. The survival tests (Fig. 1) showed that all three micro-organisms remained at almost the same levels, since no statistical differences were registered for the cell densities evaluated in the six systems and Ringer's solution (control trial). The negative control represented by noncontaminated ice cubes tested in Ringer's solution did not generate any colony development. Thus, none of the alcoholic beverages and soft drinks affected the viability of C. parapsilosis ICE214, Cr. curvatus ICE84 and P. glabrum ICE139. 
Table 2 Molecular identification of fungi

\begin{tabular}{|c|c|c|c|c|c|c|c|}
\hline \multirow[b]{2}{*}{ Species } & \multirow[b]{2}{*}{ Strain } & \multirow[b]{2}{*}{ Ice cube samples } & \multirow[b]{2}{*}{ 5.8S-ITS PCR } & \multicolumn{3}{|c|}{ Size of restriction fragments } & \multirow[b]{2}{*}{$\%$ similarity* } \\
\hline & & & & Cfol & Haelll & Hinfl & \\
\hline \multicolumn{8}{|l|}{ Yeasts } \\
\hline Candida intermedia & ICE86 & BP1 & 390 & $220+170$ & 390 & $220+170$ & 99 (FJ455102-1) \\
\hline Candida parapsilosis & ICE214 & MP3 & 510 & $300+220$ & $400+110$ & $250+270$ & 99 (KU316730.1) \\
\hline Cryptococcus curvatus & ICE84 & BP1 & 510 & $250+275$ & 490 & $235+245$ & $100(\mathrm{HQ323253 \cdot 1)}$ \\
\hline Cystobasidium slooffiae & ICE296 & HL5 & 590 & 590 & 590 & $250+340$ & 99 (KC442284.1) \\
\hline Metschnikowia sp. & ICE192 & HL3 & 390 & $220+90$ & $290+100$ & $200+190$ & 99 (KT922823.1) \\
\hline Meyerozyma guilliermondii & ICE210 & $\mathrm{HL} 4$ & 600 & $300+250$ & $395+125+80$ & $300+320$ & 99 (LC134306.1) \\
\hline Pichia guilliermondii & ICE250 & BP4 & 600 & $300+250$ & $400+125+75$ & $300+320$ & $100($ FJ468466·1) \\
\hline Rhodotorula mucilaginosa & ICE29 & MP1, MP2, MP4 & 600 & $300+225$ & $210+400$ & $350+220$ & $100($ KR632581.1) \\
\hline Yarrowia lipolytica & ICE251 & BP4 & 375 & $205+170$ & 375 & $200+175$ & $100($ KF830192.1) \\
\hline \multicolumn{8}{|l|}{ Moulds } \\
\hline Fusarium sp., & ICE33 & MP2-MP5 & n.d. & n.d. & n.d. & n.d. & $100($ LC 184244.1) \\
\hline Fusarium solani & ICE31 & MP2-MP5 & n.d. & n.d. & n.d. & n.d. & 99 (AM412594.1) \\
\hline Hansfordia sp. & ICE303 & $\mathrm{HL3}$ & n.d. & n.d. & n.d. & n.d. & 99 (KF877718.1) \\
\hline Paecilomyces sp. & ICE30 & MP2-MP5 & n.d. & n.d. & n.d. & n.d. & 96 (GQ229083·1) \\
\hline Paecilomyces lilacinus & ICE121 & BP1-BP5 & n.d. & n.d. & n.d. & n.d. & $100($ KF367485.1) \\
\hline Penicillium glabrum & ICE139 & HL1-HL5 & n.d. & n.d. & n.d. & n.d. & $100($ KX664349.1) \\
\hline Phoma leveillei & ICE122 & BP1-BP5 & n.d. & n.d. & n.d. & n.d. & 99 (KT963795·1) \\
\hline Purpureocillium sp. & ICE309 & BP1-BP5 & n.d. & n.d. & n.d. & n.d. & 96 (KY318491.1) \\
\hline Thanatephorus cucumeris & ICE311 & BP1-BP5 & n.d. & n.d. & n.d. & n.d. & 99 (KX928843.1) \\
\hline
\end{tabular}

n.d., not determined.

All values are given in bp.

*According to BlastN search in NCBI database of D1/D2 26S rRNA gene sequences for yeasts and 5.8S-ITS rRNA gene for moulds.
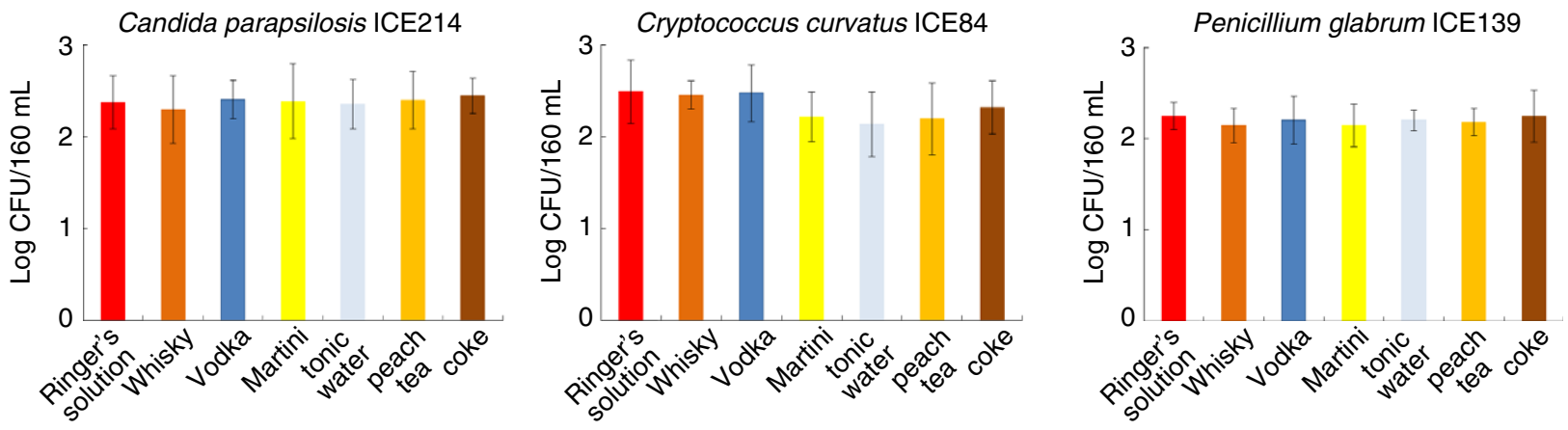

Figure 1 Change in cell density of dominating yeasts (Candida parapsilosis ICE214 and Cryptococcus curvatus ICE84) and filamentous fungi (Penicillium glabrum ICE139) isolated from food ice and added to different alcoholic beverages (whisky, vodka and Martini) and soft drinks (coke, tonic water and peach tea). [Colour figure can be viewed at wileyonlinelibrary.com]

\section{Discussion}

The survival of micro-organisms in ice cubes has been the object of several very recent studies (Awuor et al. 2016; Economou et al. 2017; Gaglio et al. 2017; Hampikyan et al. 2017; Lee et al. 2017). In general, the resistance of micro-organisms to water freezing temperatures is strictly dependent on their cytoplasm membrane. The alterations in the organization of membrane lipids (Los and Murata 2004) and the function of membraneassociated enzymes and transporters (Avery et al. 1995) are the direct consequences of the temperature reduction. The fluidity of membrane lipids is assured by the unsaturation of lipid acyl chains (Sakamoto et al. 1998; Sánchez-García et al. 2004). Although the principal microbiological risks of food ice are represented by members of Enterobacteriaceae family, with Salmonella, Shigella, Yersinia and Escherichia being mainly investigated (Falcao et al. 2002), some eukaryotic micro-organisms, such as Cryptosporidium, are cause of waterborne outbreaks (Betancourt and Rose 2004). However, to our knowledge, no investigation on the presence of 
unicellular and filamentous fungi on ice cubes has been conducted so far.

The main aim of this work was to investigate the presence of yeasts and moulds in ice, in order to provide a deepen insight on the complex microbial community associated to food ice cubes. To this purpose, several samples were collected at different levels, including domestic (small volume), restaurant (medium volume) and industrial (high volume) productions. Unicellular and filamentous fungus populations were characterized through a culture dependent polyphasic approach including viable counts, determined applying the membrane filtration method applied for water analysis, phenotypic and genotypic analyses of the isolates.

In this study, home-made ice samples were included in the survey to provide information on the hygiene of the domestic freezers. In these samples, the consistent presence of moulds (all domestic ice samples were positive for colony development) could be attributable to the freezer aerosol continuously contaminated with various foods. Penicillium are reported as common inhabitants of the domestic refrigerators (Altunatmaz et al. 2012). Thus, the aerosol of refrigerators can easily contaminate the foods stored (Salustiano et al. 2003). A similar phenomenon might be supposed for freezers when ice cubes, are not generally covered by a protective envelope.

Only six of the 60 samples of ice cubes did not contain moulds and the range of detection was between 0.8 and 195.3 CFU per $100 \mathrm{ml}$ t.i., with the highest levels found in samples from bars and pubs. Kelley et al. (2003) reported an average level of $28 \mathrm{CFU}$ per 1 in distribution systems. Regarding tap water, Gonçalves et al. (2006) reported 4 CFU per 1 as the highest level of filamentous fungi in samples collected in Portugal, while Hedayati et al. (2011) detected a range 1-22 CFU per $100 \mathrm{ml}$ for Iranian samples. A lower number of samples was positive for the presence of yeasts, but their levels, especially in the samples produced at domestic scale, were generally higher than those of moulds. Both eukaryotic groups were investigated at species level in order to better analyse the microbiological characteristics of food ice. Among the nine yeasts identified only Candida species, agents of candidal infections (van't Wout 1996), and Cr. curvatus, a rare opportunistic pathogen (Dromer et al. 1995), represent a risk for humans. Hospital sinks have been reported as a potential nosocomial source of Candida infections (Jencson et al. 2017). The incidence and epidemiology of $C$. parapsilosis fungemia was evaluated from active population-based surveillance in Barcelona and it was found that this agent accounted for $23 \%$ of all fungemias (Almirante et al. 2006), highlighting its relevance for the human health. All yeast species detected in this study are of environmental origin. Among filamentous fungi, Penicillium was confirmed to dominate the mould community of the home-made samples. Some of the species detected can be agents of human mycosis, in particular, Fusarium (Melcher et al. 1993), Pc. lilacinus (Castro et al. 1990) and Purpureocillium sp. (Luangsa-ard et al. 2011).

Presence of fungi that are known also as opportunistic human pathogens in household appliances might represent a so-far largely overlooked risk factor for fungal infections (de Hoog et al. 2009). Hence, in the second part of the work, some strains representative of the yeast and mould community found in ice cubes were evaluated for their survival in several drinks and beverages characterized by different levels of alcohol, $\mathrm{CO}_{2}, \mathrm{pH}$ and antibacterial ingredients, in order to monitor the transfer of the microbial load of ice to consumers. Thus, C. parapsilosis, Cr. curvatus (both reported as human pathogens) and P. glabrum (found in the majority of samples) were tested in whisky, vodka, Martini, coke, peach tea and tonic water, after the production of artificially contaminated ice cubes. Unlike bacteria (Gaglio et al. 2017), yeasts and moulds did not change their levels, showing that none of the drink/beverage system used the in the survival test exerted a lethal effect on their cell viability.

In conclusion, this study reported the levels and the species composition of unicellular and filamentous fungi hosted in ice cubes produced at three different levels (home-made, restaurant and industrial) finding significant differences among the production systems. The survival test indicated that the most common mode of consumption of ice cubes, through its direct addition to drinks and beverages, does not reduce the viability of these agents. Thus, the presence of potentially pathogenic yeasts and moulds in ice cubes represents a risk for consumers.

\section{Acknowledgements}

This work was financed by the National Institute of Food Ice (INGA).

\section{Conflict of Interest}

The authors declare that there is no conflict of interest.

\section{References}

Adams, R.I., Miletto, M., Taylor, J.W. and Bruns, T.D. (2013) Dispersal in microbes: fungi in indoor air are dominated by outdoor air and show dispersal limitation at short distances. ISME J 7, 1262-1273.

Alfonzo, A., Francesca, N., Sannino, C., Settanni, L. and Moschetti, G. (2013) Filamentous fungi transported by birds during migration across the Mediterranean sea. Curr Microbiol 66, 236-242. 
Almirante, B., Rodríguez, D., Cuenca-Estrella, M., Almela, M., Sanchez, F., Ayats, J., Alonso-Tarres, C., RodriguezTudela, J.L. et al. (2006) Epidemiology, risk factors, and prognosis of Candida parapsilosis bloodstream infections: case-control population-based surveillance study of patients in Barcelona, Spain, from 2002 to 2003. J Clin Microbiol 44, 1681-1685.

Altunatmaz, S.S., Issa, G. and Aydin, A. (2012) Detection of airborne psychrotrophic bacteria and fungi in food storage refrigerators. Braz J Microbiol 43, 1436-1443.

Anesio, A.M., Lutz, S., Nathan, A., Chrismas, M. and Benning, L.G. (2017). The microbiome of glaciers and ice sheets. NPJ Biofilms Microbiomes 3, 1.

Avery, S.V., Lloyd, D. and Harwood, J.L. (1995) Temperaturedependent changes in plasma-membrane lipid order and the phagocytotic activity of the amoeba Acanthamoeba castellanii are closely correlated. Biochem J 312, 811-816.

Awuor, L., Thompson, S., Thompson, B., Liberda, E.N. and Meldrum, R. (2016) Microbiological quality and handling practices of ice served in selected downtown Toronto food premises. Environ Health Rev 59, 83-87.

Barnett, H.L. and Hunter, B.B. (1998) Illustrated genera of imperfect fungi, 4th Edn. London: Burgess publishing.

Betancourt, W.Q. and Rose, J.B. (2004) Drinking water treatment processes for removal of Cryptosporidium and Giardia. Vet Parasitol 126, 219-234.

Beuchat, L.R. (2002) Ecological factors influencing survival and growth of human pathogens on raw fruits and vegetables. Microb Infect 4, 413-423.

Castro, L.G.M., Salebian, A. and Sotto, M.N. (1990) Hyalohyphomycosis by Paecilomyces lilacinus in a renal transplant patient and a review of human Paecilomyces species infections. J Med Vet Mycol 28, 15-26.

Chavasit, V., Sirilaksanamanon, K., Phithaksantayothin, P., Norapoompipat, Y. and Parinyasiri, T. (2011) Measures for controlling safety of crushed ice and tube ice in developing country. Food Control 22, 118-123.

Domsh, K.H., Gams, W. and Anderson, T.H. (2007) Compendium of soil fungi, 2nd edn. St. Paul, MN: American Phytopathological Society.

Dromer, F., Moulignier, A., Dupont, B., Guého, E., Baudrimont, M., Improvisi, L., Provost, F. and GonzalezCanali, G. (1995) Myeloradiculitis due to Cryptococcus curvatus in AIDS. AIDS 9, 395-396.

Dynowska, M. and Kisicka, I. (2005) Participation of birds in the circulation of pathogenic fungi descend from water environment: a case study of two species of Charadriformes birds. Ecohydrol Hydrobiol 5, 173-178.

Economou, V., Gousia, P., Kemenetzi, D., Sakkas, H. and Papadopoulou, C. (2017) Microbial quality and histamine producing microflora analysis of the ice used for fish preservation. J Food Saf 37, 1-8.

Esteve-Zarzoso, B., Belloch, C., Uruburu, F. and Querol, A. (1999) Identification of yeasts by RFLP analysis of the
5.8S rRNA gene and the two ribosomal internal transcribed spacers. Int J Syst Bacteriol 49, 329-337.

Falcao, J.P., Dias, A.M.G., Correa, E.F. and Falcao, D.P. (2002) Microbiological quality of ice used to refrigerate foods. Food Microbiol 19, 269-276.

Fischer, G. and Dott, W. (2003) Relevance of airborne fungi and their secondary metabolites for environmental, occupational and indoor hygiene. Arch Microbiol 179, 7582.

Francesca, N., Romano, R., Sannino, C., Le Grottaglie, L., Settanni, L. and Moschetti, G. (2014) Evolution of microbiological and chemical parameters during red wine making with extended post-fermentation maceration. Int $J$ Food Microbiol 171, 84-93.

Gaglio, R., Francesca, N., Di Gerlando, R., Mahony, J., De Martino, S., Stucchi, C., Moschetti, G. and Settanni, L. (2017) Enteric bacteria of food ice and their survival in alcoholic beverages and soft drinks. Food Microbiol 67, 1722.

Gerokomou, V., Voidarou, C., Vatopoulos, A., Velonakis, E., Rozos, G., Alexopoulos, A., Plessas, S., Stavropoulou, E. et al. (2011) Physical, chemical and microbiological quality of ice used to cool drinks and foods in Greece and its public health implications. Anaerobe 17, 351-353.

Gogu-Bogdan, M., Damoc, I., Pall, E., Niculae, M. and Spinu, M. (2014) Wild birds as potential vectors for pathogen dissemination on migration routes in the Danube Delta Wetlands. Int J Curr Microbiol App Sci 3, 890-897.

Gonçalves, A.B., Paterson, R.R.M. and Lima, N. (2006) Survey and significance of filamentous fungi from tap water. Int $J$ Hyg Environ Health 209, 257-264.

Griffin, D.M. (1960) Fungal colonization of sterile hair in contact with soil. Trans Br Mycol Soc 43, 583-596.

Hageskal, G., Lima, N. and Skaar, I. (2009) The study of fungi in drinking water. Mycol Res 113, 165-172.

Hampikyan, H., Bingol, E.B., Cetin, O. and Colak, H. (2017) Microbiological quality of ice and ice machines used in food establishments. J Water Health 15, 410-417.

Hedayati, M.T., Mayahi, S., Movahedi, M. and Shokohi, T. (2011) Study on fungal flora of tap water as a potential reservoir of fungi in hospitals in Sari city. Iran. J Mycol Med 21, 10-14.

de Hoog, G.S., Guarro, J., Gene, J. and Figueras, M.J. (2009) Atlas of clinical fungi, 3rd Edn. Utrecht/Reus: Centraalbureau voor Schimmelcultures/Universitat Rovira i Virgili.

Jacobson, K.M. (1997) Moisture and substrate stability determine VA-mycorrhizal fungal community distribution and structure in an arid grassland. J Arid Environ 35, 5975.

Jencson, A.L., Cadnum, J.L., Piedrahita, C. and Donskey, C.J. (2017) Hospital sinks are a potential nosocomial source of Candida infections. Clin Infect Dis. https://doi.org/10. 1093/cid/cix629. (in press). 
Kelley, J., Kinsey, G., Paterson, R., Brayford, D., Pitchers, R. and Rossmore, H. (2003) Identification and control of fungi in distribution systems. Denver: Awwa Research Foundation and American Water Works Association.

Lateef, A., Oloke, J.K., Kana, E.B.G. and Pacheco, E. (2006) The microbiological quality of ice used to cool drinks and foods in Ogbomoso Metropolis, Southwest, Nigeria. Int $J$ Food Saf 8, 39-43.

Lee, K.H., Ab Samad, L.S., Lwin, P.M., Riedel, S.F., Magin, A., Bashir, M., Vaishampayan, P.A. and Lin, W.J. (2017) On the Rocks: microbiological quality and microbial diversity of packaged ice in Southern California. J Food Prot 80, 1041-1049.

Li, Y., Brackett, R.E., Shewfelt, R.L. and Beuchat, L.R. (2001) Changes in appearance and natural microflora on iceberg lettuce treated in warm, chlorinated water and then stored at refrigeration temperature. Food Microbiol 18, 299-308.

Los, D.A. and Murata, N. (2004) Membrane fluidity and its roles in the perception of environmental signals. Biochim Biophys Acta 1666, 142-157.

Luangsa-ard, J., Houbraken, J., van Doorn, T., Hong, S.B., Borman, A.M., Hywel-Jones, N.L. and Samson, R.A. (2011) Purpureocillium, a new genus for the medically important Paecilomyces lilacinus. FEMS Microbiol Lett 321, 141-149.

Melcher, G.P., McGough, D.A., Fothergill, A.W., Norris, C. and Rinaldi, M.G. (1993) Disseminated hyalohyphomycosis caused by a novel human pathogen, Fusarium napiforme. J Clin Microbiol 31, 1461-1467.

Nichols, G., Gillespie, I. and de Louvois, J. (2000) The microbiological quality of ice used to cool drinks and ready-to-eat from retail and catering premises in the United Kingdom. J Food Prot 63, 78-82.

Noor Izani, N.J., Zulaikha, A.R., Mohamad, Noor M.R., Amri, M.A. and Mahat, N.A. (2012) Contamination of faecal coliforms in ice cubes sampled from food outlets in Kubang Kerian, Kelantan. Trop Biomed 29, 71-76.

Northcutt, J.K. and Smith, D. (2010) Microbiological and chemical analyses of ice collected from a commercial poultry processing establishment. Poult Sci 89, 145-149.

Novak Babič, M., Zalar, P., Ženko, B., Schroers, H.J., Džeroski, S. and Gunde-Cimerman, N. (2015) Candida and Fusarium species known as opportunistic human pathogens from customer-accessible parts of residential washing machines. Fungal Biol 119, 95-113.
Novak Babič, M., Zalar, P., Ženko, B., Džeroski, S. and Gunde-Cimerman, N. (2016) Yeasts and yeast-like fungi in tap water and groundwater and their transmission to household appliances. Fungal Ecol 20, 30-39.

Novak Babič, M., Gunde-Cimerman, N., Vargha, M., Tischner, Z., Magyar, D., Veríssimo, C., Sabino, R., Viegas, C. et al. (2017) Fungal contaminants in drinking water regulation? A tale of ecology, exposure, purification and clinical relevance. Int J Environ Res Public Health 636, 1-44.

O'Donnell, K. (1993) Fusarium and its near relatives. In The fungal holomorph: mitotic, meiotic and pleomorphic speciation in fungal systematics ed. Reynolds, D.R. and Taylor, J.W. pp. 225-233. Wallingford: Centre for Agriculture and Bioscience International.

O’Donnell, K., Cigelnik, E. and Nirenberg, H.I. (1998) Molecular systematics and phylogeography of the Gibberella fujikuroi species complex. Mycologia 90, 465493.

Sakamoto, T., Shen, G., Higashi, S., Murata, N. and Bryant, D.A. (1998) Alteration of low-temperature susceptibility of the cyanobacterium Synechococcus sp. PCC 7002 by genetic manipulation of membrane lipid unsaturation. Arch Microbiol 169, 20-28.

Salustiano, V.C., Andrade, N.J., Brandão, S.C.C., Azeredo, R.M.C. and Lima, S.A.K. (2003) Microbiological air quality of processing areas in a dairy plant as evaluated by the sedimentation technique and a one-stage air sampler. Braz J Microbiol 34, 255-259.

Sánchez-García, A., Mancha, M., Heinz, E. and MartínezRivas, J.M. (2004) Differential temperature regulation of three sunflower microsomal oleate desaturase (FAD2) isoforms overexpressed in Saccharomyces cerevisiae. Eur J Lipid Sci Tech 106, 583-590.

Ukwo, S.P., Ndaeyo, N.U. and Udoh, E.J. (2011) Microbiological quality and safety evaluation of fresh juices and edible ice sold in Uyo Metropolis, South-South, Nigeria. Int J Food Saf 13, 374-378.

Viljoen, B.C. (2001) The interaction between yeasts and bacteria in dairy environments. Int J Food Microbiol 69, 37-44.

van 't Wout, J.W. (1996) Fluconazole treatment of candidal infections caused by non-Albicans Candida species. Eur J Clin Microbiol Infect Dis 15, 238-242. 